\title{
Surgery after Primary Systemic Chemotherapy in Patients with Breast Cancer
}

\author{
Wolfgang Eiermann Beyhan Ataseven \\ Frauenklinik vom Roten Kreuz, München, Germany
}

\section{Key Words}

Primary systemic therapy - Breast cancer - Surgery .

Sentinel biopsy - Local recurrence rate

\section{Summary}

Application of systemic therapy in curable breast cancer for the purpose of a 'neoadjuvant' or rather a primary systemic therapy (PST) prior to surgery is increasingly preferred. There are considerable advantages concerning this concept of treatment for both clinical and scientific reasons. An increasing rate of breast conserving therapies has top priority for the affected patients. There is also a notable positive psychological effect for the patients caused by the shrinkage of the tumor as a consequence of a therapy-achieved positive tumor response. Nevertheless, physicians are faced with the challenge of PST and its achieved effects on the tissue. They occur especially as patients undergo therapy as well as during and after surgery.

\section{Introduction}

From time to time, primary systemic therapy (PST) is more commonly used as the primary therapeutic option in patients with non-metastatic breast cancer. PST was first applied to patients with locally advanced, inoperable cancers. During the last 15 years, many studies have shown sufficient results which demonstrate the safety and efficiency of PST. Subsequently, this kind of therapy could also be applied to patients with smaller tumors.

\author{
Schlüsselwörter \\ Primär systemische Therapie - Mammakarzinom · \\ Operation · Sentinelbiospie · Lokalrezidivrate
}

\section{Zusammenfassung}

Die systemische Therapie beim kurablen Mammakarzinom wird zunehmend der Operation im Sinne einer «neo-adjuvanten» Behandlung - oder besser primär systemischen Therapie (PST) - vorangestellt. Sowohl aus klinischen als auch aus wissenschaftlichen Gründen bietet dieses Behandlungskonzept viele Vorteile. Für die Betroffenen steht die Möglichkeit im Vordergrund, die Rate der brusterhaltenden Operationen erhöhen zu können. Nicht zu vernachlässigen ist auch der positive psychologische Effekt, der durch das Schrumpfen, und somit Ansprechen des Tumors auf die Therapie, erreicht wird. Nichtsdestotrotz stellt aber die PST eine große Herausforderung für die Kliniker dar, sowohl im Therapieverlauf als auch während und nach der Operation mit den erzielten Veränderungen am Gewebe umzugehen.

Current recommendations for PST are periodically reviewed [1]. However, new questions concerning the PST practice do occur: Which are the advantages / disadvantages of PST compared to adjuvant treatment? Can the choice of treatment be optimized or adapted to a special type of tumor? Are there tumors that are stimulated rather than eliminated by PST, and does clinical examination provide sufficient safety for patients? Which challenges appear concerning surgery after PST, and can the established guidelines be used or do they have to be replaced by new rules? Is patient monitoring including pal-

\begin{tabular}{ll}
\hline KARGER & ( 2006 S. Karger GmbH, Freiburg \\
Fax +49 761 4520714 & Accessible online at: \\
$\begin{array}{l}\text { E-mail Information@Karger.de } \\
\text { www.karger.com }\end{array}$ & www.karger.com/brc
\end{tabular}


Table 1. Randomized studies and BCT rates

\begin{tabular}{lllll}
\hline Study/author [Ref.] & Patients, $n$ & $\begin{array}{l}\text { BCT rate } \\
\text { ACHT, } \%\end{array}$ & $\begin{array}{l}\text { BCT rate } \\
\text { PST-1, \% }\end{array}$ & $\begin{array}{l}\text { BCT rate } \\
\text { PST-2, \% }\end{array}$ \\
\hline NSABP B-18 [2] & 1,523 & 60 & 68 & \\
ECTO [3] & 893 & 34 & 71 & \\
EORTC [4] & 698 & 21 & 37 & \\
Scholl [5] & 390 & 77 & 82 & 63 \\
NSABP B-27 [11] & 2,189 & & 61 & 75 \\
Gepar-duo [12] & 913 & & 66 & 61 \\
AGO [13] & 678 & & 50 & 72 \\
Gepartrio-Pilot [14] & 286 & & \\
\hline
\end{tabular}

$\mathrm{ACTH}=$ Adjuvant chemotherapy; PST-1/2 = primary systemic chemotherapy regimen 1/2; $\mathrm{BCT}=$ breast conserving therapy.

Table 2. BCT rate after primary endocrine therapy

\begin{tabular}{|c|c|c|c|}
\hline Study/author [Ref.] & Patients, n & Therapy & $\mathrm{BCT}$ rate, $\%$ \\
\hline Eiermann [15] & 337 & letrozole vs. tamoxifen & 45 vs. 35 \\
\hline IMPACT/Smith [16] & 330 & $\begin{array}{l}\text { anastrozole vs. tamoxifen vs } \\
\text { anastrozole + tamoxifen }\end{array}$ & 46 vs. 22 vs. 26 \\
\hline Semiglazov [17] & 121 & CHT $(4 \times$ APac $)$ vs. anastrozole & 21 vs. 38 \\
\hline
\end{tabular}

$\mathrm{BCT}=$ Breast conserving therapy $\mathrm{CHT}=$ chemotherapy $; \mathrm{APac}=$ doxorubicin $/$ paclitaxel. pation, mammography and ultrasound sufficient during therapy? Or do other imaging diagnostics, such as positron emission tomography (PET) or magnetic resonance imaging (MRI), have to be employed for an early evaluation of a successful therapy? Which information can provide an in vivo test from the tumor during PST, and how can these results be utilized for further treatment? And last but not least, what about patients who do not show any therapy response and are, in a way, therapy-resistant or show signs of progression?

At the moment, many of these questions cannot be answered. This overview discusses current data regarding surgical procedure after PST.

\section{Does PST Contribute to an Increased Rate of Breast Conserving Therapy?}

Long-term scientific observations of randomized multicenter studies comparing adjuvant chemotherapy with PST have shown no difference in disease free survival (DFS) and overall survival (OS) [2-6]. Subsequently, PST is considered to be a safe alternative to adjuvant chemotherapy. However, PST provides the positive effect of significantly increasing the rate of breast conserving therapies (table 1). The difficulty for the surgeon consists in deciding whether tumor-free excision margins can be gained. For this purpose, precise diagnostic checkup examinations during therapy (e.g. ultrasound, mammography, palpation, metric photo documentation) are necessary. In the case of a clinical complete remission (cCR), the tumor bed has to be tagged and excised based on the checkup data. Additionally, the tumor response rate can vary considerably (table 1). This explains why the re-operation rate is comparatively higher (up to $20 \%$ ). Views differ on whether the excision should take place within the 'old' or 'new' tumor margins. An excision within the old tumor margins ensures that even scattered tumor islands are captured. On the other hand, in these cases, a breast conserving therapy is not possible or cosmetically not sustainable. As explained in the following text, the local recurrence rate after PST in comparison to adjuvant systemic therapy is not significantly increased. This justifies operating primarily within the new tumor borders, and, as far as histologically verified, to make no further advances.

By use of a preoperative hormonal therapy, the rate of breast conserving therapy can also be increased (table 2). However, currently, this kind of therapy is an alternative to neoadjuvant chemotherapy only for elder patients who have hormone receptor-positive tumors, a bad performance status and suffer from internal diseases.

An important parameter to evaluate the result of PST is the rate of pathological complete remissions ( $\mathrm{pCR}$ ) which represents a significant predictor for DFS [7]. Patients with tumors that could be eliminated completely (pCR) by PST had by comparison a significantly better disease-related survival rate (DFS, OS) [2, 4]. It is not clear whether the elimination of invasive tumor parts can be seen as a pCR, or whether any invasive and pre-invasive tumor cells have to be absent in both the breast and lymph tissue. 
Table 3. Local recurrence rate adjuvant/neoadjuvant chemotherapy

\begin{tabular}{ccll}
\hline Author [Ref.] & $\begin{array}{l}\text { Patients, } \\
\mathrm{n}\end{array}$ & $\begin{array}{l}\text { Local } \\
\text { recurrence } \\
\text { rate, \% }\end{array}$ & $\begin{array}{l}\text { Median } \\
\text { observation time, } \\
\text { months }\end{array}$ \\
\hline $\begin{array}{c}\text { Scholl [5] } \\
\text { Adjuvant }\end{array}$ & 190 & 8.2 & 54 \\
$\quad$ Neoadjuvant & 200 & 10.6 & \\
Makris [18] & & & \\
Adjuvant & 144 & 2.7 & 48 \\
Neoadjuvant & 149 & 3.5 & \\
Wolmark [2] & & 7.6 & 60 \\
Adjuvant & 743 & 10.7 & \\
Neoadjuvant & 752 & & \\
\hline
\end{tabular}

Table 4. Validity of sentinel lymph node biopsy; metaanalysis

\begin{tabular}{lcc}
\hline Parameter & $\begin{array}{l}\text { SNB - primary, } \\
\text { Kim [10] }\end{array}$ & $\begin{array}{l}\text { SNB after PST, } \\
\text { Xing [19] }\end{array}$ \\
\hline Studies, $\mathrm{n}$ & 69 & 21 \\
Patients, $\mathrm{n}$ & 8,059 & 1,273 \\
Detection rate, \% & $96(41-100)$ & $90(72-100)$ \\
False-negative rate, \% & $7.2(0-29)$ & $12(0-33)$ \\
\hline
\end{tabular}

SNB = Sentinel lymph node biopsy; PST = primary systemic chemotherapy.

\section{Is the Local Recurrence Rate Different after PST and Surgery?}

A metaanalysis consisting of 9 studies (approximately 4,000 patients) gives evidence of a significant increase in the local recurrence rate $(\mathrm{RR}=1.22,95 \%$ confidence interval $(\mathrm{CI})$ 1.04-1.43; $\mathrm{p}=0.015$ ) [8]. When scrutinizing, it emerges that the authors describe a very high local recurrence rate in 3 studies. In these studies, considerably more patients received radiation therapy directly after PST without surgery (as compared to adjuvant therapy patients). It is more a problem of deviating from standard procedure than a significant increase in local recurrence after PST. Nowadays, according to standard procedure with surgery and postoperative radiotherapy, there is no significant increase in local recurrence although there is a tendency for increased recurrence in the PST group (table 3). Chen et al. [8] were able to prove that with the following parameters the risk of local and locoregional recurrence is significantly higher: clinical N2/3 tumors, rest tumor after PST $>2 \mathrm{~cm}$, multifocal tumor, and lymphovascular invasion.

Presently, there is a common consensus that after breast conserving therapy beyond PST external beam radiation therapy should be done. A future option may be to combine simultaneous intraoperative radiotherapy with external beam radio-

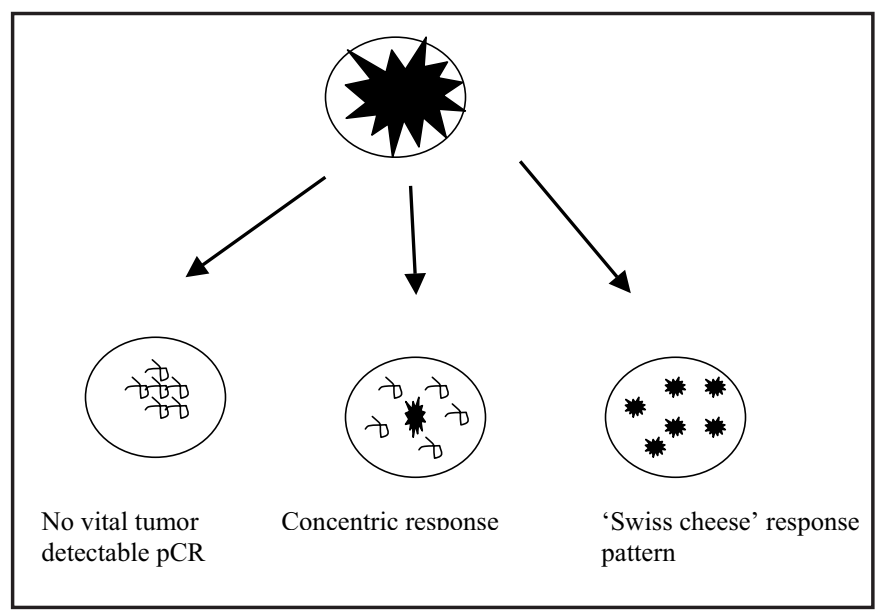

Fig. 1. Tumor response pattern after primary systemic chemotherapy (PST).

therapy to achieve a decreased local recurrence rate. Intraoperative radiotherapy has the advantage of detecting the primary tumor location and hence to protect neighboring tissue.

\section{What is the Ranking of Sentinel Node Biopsy after PST?}

With sentinel node biopsy, a decrease in morbidity can be achieved. Now, the question arises whether sentinel node biopsy after PST is safe enough. Various questions arise: Is there any change after PST in the lymphatic pattern of the breast? Is the effect of the therapy in the sentinel node the same as in the nonsentinel node? Is the sentinel node biopsy after downstaging in the axilla (before PST N+, after PST N-) reliable? Most of these questions have not yet been completely answered. Randomized studies have to be carried out to find satisfactory answers. In a metaanalysis Xing et al. [19] collected the data of 21 studies with 1,273 patients (table 4). The median detection rate was $90 \%(72-100 \%, 95 \%$ CI $85-90 \%)$, sensitivity $88 \%(67-100 \%, 95 \%$ CI $84-91 \%)$. The authors concluded that the sentinel node biopsy was a reliable procedure after PST. The most important study out of this metaanalysis with 428 patients did not find any significant differences in the detection rate of the sentinel node in relation to age, tumor size, nodal status, and location of the tumor [10]. However, a non significant increase in the false-negative rate was detected with increasing tumor size $(\leq 2 \mathrm{~cm}$ : $5 \% ; 2.1-4 \mathrm{~cm}$ : $9.7 \%$; $>4 \mathrm{~cm}: 13.8 \% ; \mathrm{p}=0.33)$. Overall, the safety of sentinel node biopsy is high enough taking into consideration all criteria (before PST: tumor size $<3 \mathrm{~cm}$, N0, sufficient clinical experience). But sentinel node biopsy should not be performed outside of randomized studies. One innovative approach is to carry out sentinel node biopsy before PST. The information gained could additionally support the indication for PST in cases of positive lymph nodes. 


\section{Conclusion}

High clinical experience of the interdisciplinary team is required for planning, conducting and operation after PST. Radiologists, surgeons and pathologists have to evaluate the achieved results together. A mutual flow of information is essential. In the case of cCR, it is a big challenge to estimate with high safety whether to make an excision in the former tumor bed without leaving tumor cells in situ. For this pur- pose, there are different approaches to mark the former tumor bed (e.g. clip marking). The resection within the new tumor borders is reliable if histology confirms an $\mathrm{R} 0$ resection.

The procedure of sentinel node biopsy should only be performed in exceptional cases after PST, as so far there are no sufficient data and long-term results. The downstaging of the axilla is seen in about $20 \%$ after PST. Especially in these cases, it is unclear whether sentinel node biopsy after PST results in insufficient therapy.

\section{References}

1 Kaufmann M, von Minckwitz G, Smith R, Valero V, Gianni L, Eiermann W, Howell A, Costa SD, Beuzeboc P, Untch M, Blohmer J-U, Sinn H-P, Sittek R, Souchon R, Tulusan AH, Volm T, Senn H-J. International expert panel on the use of primary (preoperative) systemic treatment of operable breast cancer: review and recommendations. J Clin Oncol 2003;21:2600-2608.

2 Wolmark N, Wang J, Mamounas E, Bryant J, Fisher B: Preoperative chemotherapy in patients with operable breast cancer: nine-year results from national surgical adjuvant breast and bowel project B-18. J Natl Cancer Inst Monogr 2001;30:96-102.

3 Gianni L, Baselga J, Eiermann W, Porta VG, Semiglazov V, Garcia-Conde J, Zambetti M, Valagussa P, Bonadonna G, for the ECTO Study Group, Milano, Italy: First report of the European Cooperative Trial in operable breast cancer (ECTO): effects of primary systemic therapy (PST) on local-regional disease. Proc Am Soc Clin Oncol2002;21:abstr 132.

4 Van der Hage JA, van de Velde CJ, Julien JP, Tubiana-Hulin M, Vandervelden C, Duchateau L: Preoperative chemotherapy in primary operable breast cancer: results from the European Organization for Research and Treatment of Cancer trial 10902. J Clin Oncol 2001;19:4224-37.

5 Scholl SM, Fourquet A, Asselain B, Pierga JY, Vilcoq JR, Durand JC, Dorval T, Palangie T, Jouve M, Beuzeboc P: Neoadjuvant versus adjuvant chemotherapy in premenopausal patients with tumours considered too large for breast conserving surgery: preliminary results of a randomised trial: S6. Eur J Cancer 1994:30A:645-52.

6 Mauri D, Pavlidis N, Ioannidis JP: Neoadjuvant versus adjuvant systemic treatment in breast cancer: a meta-analysis. J Natl Cancer Inst 2005;97: 188-94.

7 Bear HD, Anderson S, Smith RE, Geyer CE Jr, Mamounas EP, Fisher B, Brown AM, Robidoux A, Margolese R, Kahlenberg MS, Paik S, Soran A, Wickerham DL, Wolmark N: Sequential preoperative or postoperative docetaxel added to preoperative doxorubicin plus cyclophosphamide for operable breast cancer: National Surgical Adjuvant Breast and Bowel Project Protocol B-27. J Clin Oncol 2006;24:2019-27.
8 Chen AM, Meric-Bernstam F, Hunt KK, Thames HD, Oswald MJ, Outlaw ED, Strom EA, McNeese MD, Kuerer HM, Ross MI, Singletary SE, Ames FC, Feig BW, Sahin AA, Perkins GH, Schechter NR, Hortobagyi GH, Buchholz TA: Breast conservation after neoadjuvant chemotherapy: the M.D. Anderson Cancer Center experience. J Clin Oncol 2004;22:2303-12.

-9 Mamounas EP, Brown A, Anderson S, Smith R, Julian T, Miller B, Bear HD, Caldwell CB, Walker AP, Mikkelson WM, Stauffer JS, Robidoux A, Theoret H, Soran A, Fisher B, Wickerham DL, Wolmark N: Sentinel node biopsy after neoadjuvant chemotherapy in breast cancer: results from National Surgical Adjuvant Breast and Bowel Project Protocol B-27. J Clin Oncol 2005;23:2694-702. Erratum in J Clin Oncol 2005;23:4808.

10 Kim T, Giuliano AE, Lyman GH: Lymphatic mapping and sentinel lymph node biopsy in early-stage breast carcinoma: a metaanalysis. Cancer 2006;106: 4-16.

11 Bear HD, Anderson S, Brown A, Smith R, Mamounas EP, Fisher B, Margolese R, Theoret H, Soran A, Wickerham DL, Wolmark N; National Surgical Adjuvant Breast and Bowel Project Protocol B-27: The effect on tumor response of adding sequential preoperative docetaxel to preoperative doxorubicin and cyclophosphamide: preliminary results from National Surgical Adjuvant Breast and Bowel Project Protocol B-27. J Clin Oncol 2003;21: 4165-74.

12 Jackisch C, von Minckwitz G, Eidtmann H, Costa SD, Raab G, Blohmer JU, Schutte M, Gerber B, Merkle E, Gademann G, Lampe D, Hilfrich J, Tulusan AH, Caputo A, Kaufmann M: Dose-dense biweekly doxorubicin/docetaxel versus sequential neoadjuvant chemotherapy with doxorubicin/cyclophosphamide/docetaxel in operable breast cancer: second interim analysis. Clin Breast Cancer 2002;3:276-80.

13 Untch M, Konecny G, Ditsch N, Sorokina Y, Moebus V, Muck B, Kuhn W, Bastert G, Werner C, Thomssen C, Wallwiener D, Albert U, Bothmann G, Kreienberg R, Lück HJ: Dose-dense sequential epirubicin-paclitaxel as preoperative treatment of breast cancer: results of a randomised AGO study. Proc Am Soc Clin Oncol 2002;21:abstr 133.
14 Minckwitz G, Blohmer JU, Raab G, Löhr A, Gerber B, Heinrich G, Eidtmann H, Kaufmann M, Hilfrich J, Jackisch $\mathrm{C} 0$, Zuna I, Costa SD: In vivo chemosensitivity-adapted preoperative chemotherapy in patients with early-stage breast cancer: the GEPARTRIO pilot study. Ann Oncol 2005;16: 56-63.

15 Eiermann W, Paepke S, Appfelstaedt J, LlombartCussac A, Eremin J, Vinholes J, Mauriac L, Ellis M, Lassus M, Chaudri-Ross HA, Dugan M, Borgs M Preoperative treatment of postmenopausal breast cancer patients with letrozole: a randomized double-blind multicenter study. Ann Oncol 2001;12: 1527-32.

16 Smith IE, Dowsett M, Ebbs SR, Dixon JM, Skene A, Blohmer JU, Ashley SE, Francis S, Boeddinghaus I, Walsh G: Neoadjuvant treatment of postmenopausal breast cancer with anastrozole, tamoxifen, or both in combination: the Immediate Preoperative Anastrozole, Tamoxifen, or Combined with Tamoxifen (IMPACT) multicenter double-blind randomized trial. J Clin Oncol 2005;23:5108-16.

17 Semiglazov VF, Semiglazov V, Ivanov V, Bozhok A, Ziltsova E, Paltuev R, Dashian G, Kletzel A, Topuzov E, Berstein L; N.N. Petrov Research Institute of Oncology: The relative efficacy of neoadjuvant endocrine therapy vs chemotherapy in postmenopausal women with ER-positive breast cancer. J Clin Oncol ASCO Proc Ann Meet (postmeeting ed) 2004;22:519

18 Makris A, Powles TJ, Ashley SE, Chang J, Hickish T, Tidy VA, Nash AG, Ford HT: A reduction in the requirements for mastectomy in a randomized trial of neoadjuvant chemoendocrine therapy in primary breast cancer. Ann Oncol 1998;9:1179-84.

19 Xing Y, Foy M, Cox DD, Kuerer HM, Hunt KK Cormier JN: Meta-analysis of sentinel lymph node biopsy after preoperative chemotherapy in patients with breast cancer. Br J Surg 2006;93:539-46. 